【総 説】

\section{ジャワしょうがバングレ Java Ginger Bangle}

鈴木信孝 ${ }^{1, *}$, 許 鳳浩 ${ }^{1}$, 上馬塲和夫 ${ }^{2}$ Nobutaka SUZUKI ${ }^{1,}$, , Hoko KYO', Kazuo UEBABA ${ }^{3}$

1 金沢大学大学院医薬保健学総合研究科 臨床研究開発補完代替医療学講座

2 帝京平成大学

\section{【要 旨】}

ジャワしょうがのエキス食品であるジャワしょうが バングレの成分, 安全性や健康機能性, とくに脳機 能賦活作用についての最新知見を紹介した. ジャワ しょうがバングレは, in vitroにおいて NGF 非存 在下でも神経細胞の新生ならびに突起伸展作用を有 することが徐々に明らかとなってきた. また, 動物 実験で, 主成分バングレンが血液脳関門を通過する ことや空間学習能力と記憶力の改善作用をもたらす ことなどが報告されている. さらに，ヒトにおいて 軽度認知障害 $(\mathrm{MCl})$ に対する効果の検討も始まっ た. 以上, ジャワしょうがバングレは, 認知症に対 する機能性食品として有望なものの一つであると思 われた.

\section{【キーワード】}

ジャワしょうがバングレ, 神経栄養因子様活性化合 物, バングレン, 認知症, 軽度認知障害, MoCA-J

\section{1. はじめに}

しょうがは，インド，中国，ギリシャなど世界各地で， 古来より健康によい食材として用いられてきた。 日本に おいても，しょうがは，消化不良，吐き気，冷え症，月 経困難症等によいと認識されており, 健康イメージが高 い食品素材として知られている.

一方，「ジャワしょうが」(Zingiber purpureum) は, 一般的なしょうが(Zingiber officinale) と同じショウガ 科 (Zingiberaceae) に属する食用作物であるが，まだ日 本ではなじみは少ない（図 1)。インドネシアでは, ジャ ワしょうがは「Bangle」(バングレ）と呼ばれ，古くから スパイスとして使用されてきた。また，インドネシアの 伝統薬である Jamu（ジャムー）のひとつとして，風邪， 胃痛，頭痛，リウマチ，肥満などに対して有効な生薬と しても知られている.

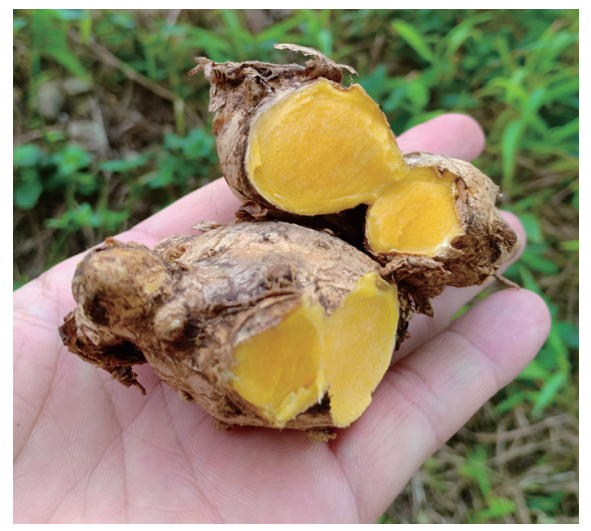

図 1 ジャワしょうが

近年, 徳島文理大学で神経栄養因子様活性化合物を含 有するジャワしょうがが報告されたこと ${ }^{1,2)}$ を契機に, 主 としてわが国で基礎的研究が急速に進んできた。一方, ジャワしょうが中の不要な成分の除去や抽出法にも工夫 が加えられ，エキスの特許化にも成功した ${ }^{3)}$. また，当 該エキスはジャワしょうがバングレと命名された。

ジャワしょうがの研究進捗とともに，インドネシアの 人・環境・農業・経済が循環できるシステムも構築され， インドネシア農業省の公認を受けた ASMELINDO の日本 支部としてNPO 法人「JASMELINDO」も創設された。 さらに，生物多様性条約に基づき，インドネシア政府関 係者の指導のもと, 現地農民の支援を行いつつ, 高品質 なジャワしょうがの無農薬栽培システムも構築された。 なお, ジャワしょうがは, 成長が遅く, 2 年以上の期間 を要する作物であり, 貴重なしょうがである。

本稿では, ジャワしょうがバングレの成分, 安全性や 健康機能性, とくに脳機能賦活作用についての最新知見 を紹介したい. 


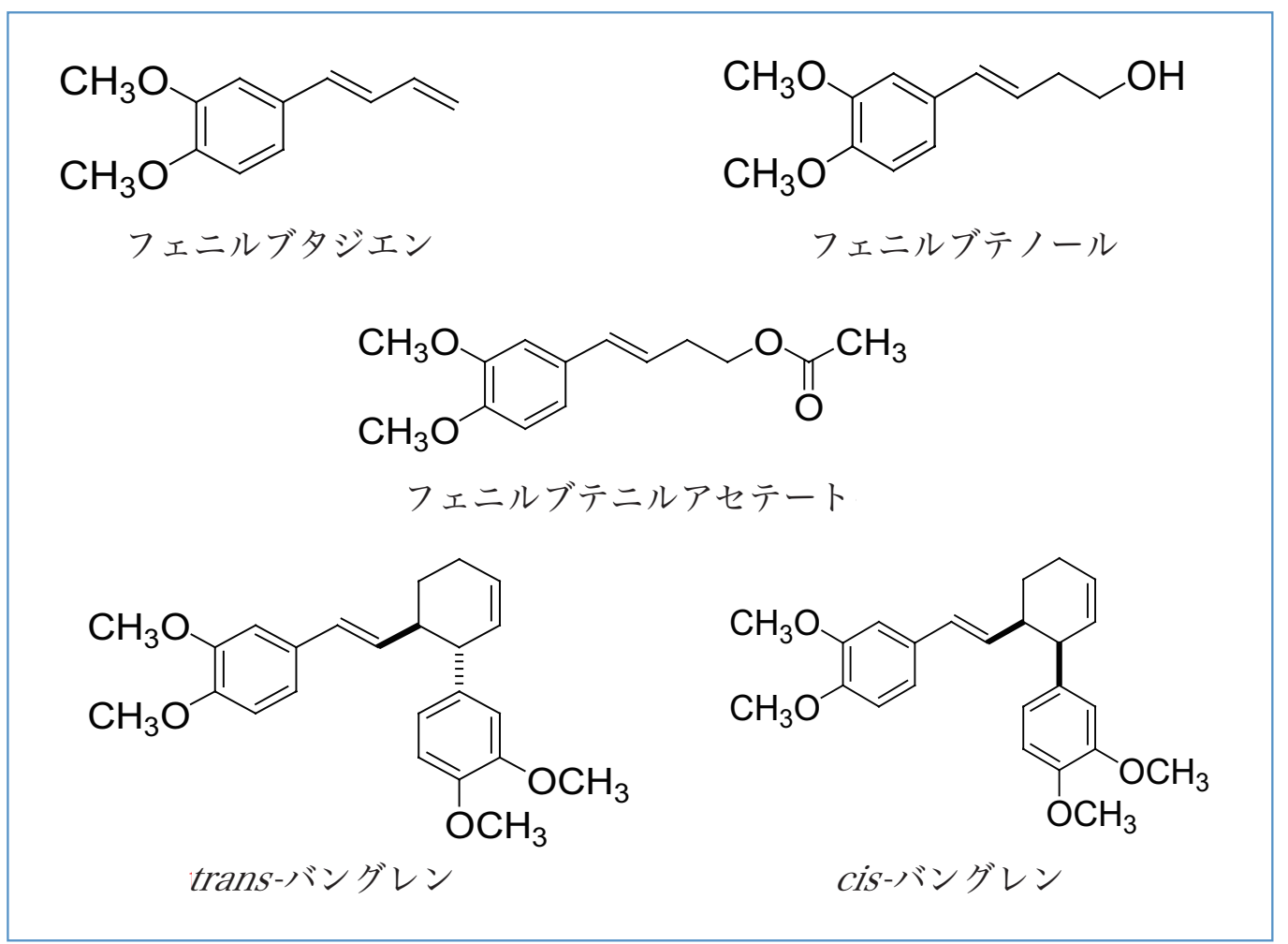

図 2 ジャワしょうがの特徵的な成分

\section{2. ジャワしょうが及びそのエキス}

ジャワしょうがは, 植物分類学上, ショウガ科ショウガ 属に分類され, Zingiber purpureum, Zingiber cassumunar やZingiber montanum という 3 つの学名を持つ植物であ る ${ }^{4)}$.

これまで，日本においてこのジャワしょうがエキスを利 用した例として，肌の美白効果を利用した化粧品 ${ }^{5)}$ が挙げ られるが，機能性食品としての利用はジャワしょうがバン グレが初めてである.

ジャワしょうがには，特徵的な成分としてフェニルブタ ジエン，フェニルブテノール，フェニルブテニルアセテー トなどのフェニルブテノイドモノマーに加え，フェニルブ タジエンのダイマーであるバングレンの幾何異性体である trans-バングレンとcis-バングレンが含まれている（図 2). このほか, クルクミンをはじめとするクルクミノイドもわ ずかながら存在する。一方，一般的なしょうがに含まれて いる成分であるジンゲロールやショウガオールは含まれて おらず (in press)，極めてユニークなしょうがといえよう。 また，犬の玉ねぎ中毒の原因成分であるアリルプロピルジ スルフィドはジャワしょうがバングレに含まれていないこ とも分かっている (in press)，以上のことから，犬や猫な ど伴侶動物のサプリメントとしても応用可能であると考え られている。

\section{3. ジャワしょうがバングレの安全性}

ジャワしょうがは，そもそもインドネシアを中心に古く
から食品や伝統薬として活用されており，その食歴は長く， 安全性が高い作物である。

ジャワしょうがバングレの安全性は詳細に検証されて いる。ラットを用いた急性毒性試験（最大 $2,000 \mathrm{mg} / \mathrm{kg} /$ 日), 覀急性毒性試験（最大 $1,000 \mathrm{mg} / \mathrm{kg} /$ 日, 90 日間投 与), 健常者を用いたヒ卜安全性試験(最大 $850 \mathrm{mg} /$ 人/日, 28 日間投与）が実施されており，いずれも異常は認めら れていない ${ }^{6)}$. さらに, 変異原性試験（遺伝毒性試験）と して，マウスに最大 $2,000 \mathrm{mg} / \mathrm{kg} /$ 日のエキスを投与して 骨髄細胞の遺伝子変異の有無を調べる小核試験でも異常は 認められていない (in press).

また，図 3 のごとく，健常者がジャワしょうがバングレ を経口揁取した際のバングレンの血中動態も明らかにされ ており, trans-バングレンと cis-バングレンともに最高血 漿中濃度到達時間は 1.8 時間後, 最高血漿中濃度もそれぞ れ $22.61 \pm 6.70 \mathrm{ng} / \mathrm{mL}, 17.73 \pm 5.61 \mathrm{ng} / \mathrm{mL}$ であり, 蓄積 毒性作用もほとんどないことが示唆されている ${ }^{6)}$.

以上のことから，ジャワしょうがバングレは，通常の量 を摂取する限り, 安全性の高い食品であるといえる。

\section{4. ジャワしょうがバングレの脳機能改善作用}

ジャワしょうがバングレの最も注目すべき健康機能性 は，脳機能改善作用である。高齢化が進む現在，認知症は 大きな社会問題であり，その解決は喫緊の課題となってい る。様々な製薬企業においても, 脳機能改善薬の開発は進 んでいるものの, 高い治療効果を有する画期的な新薬の登 


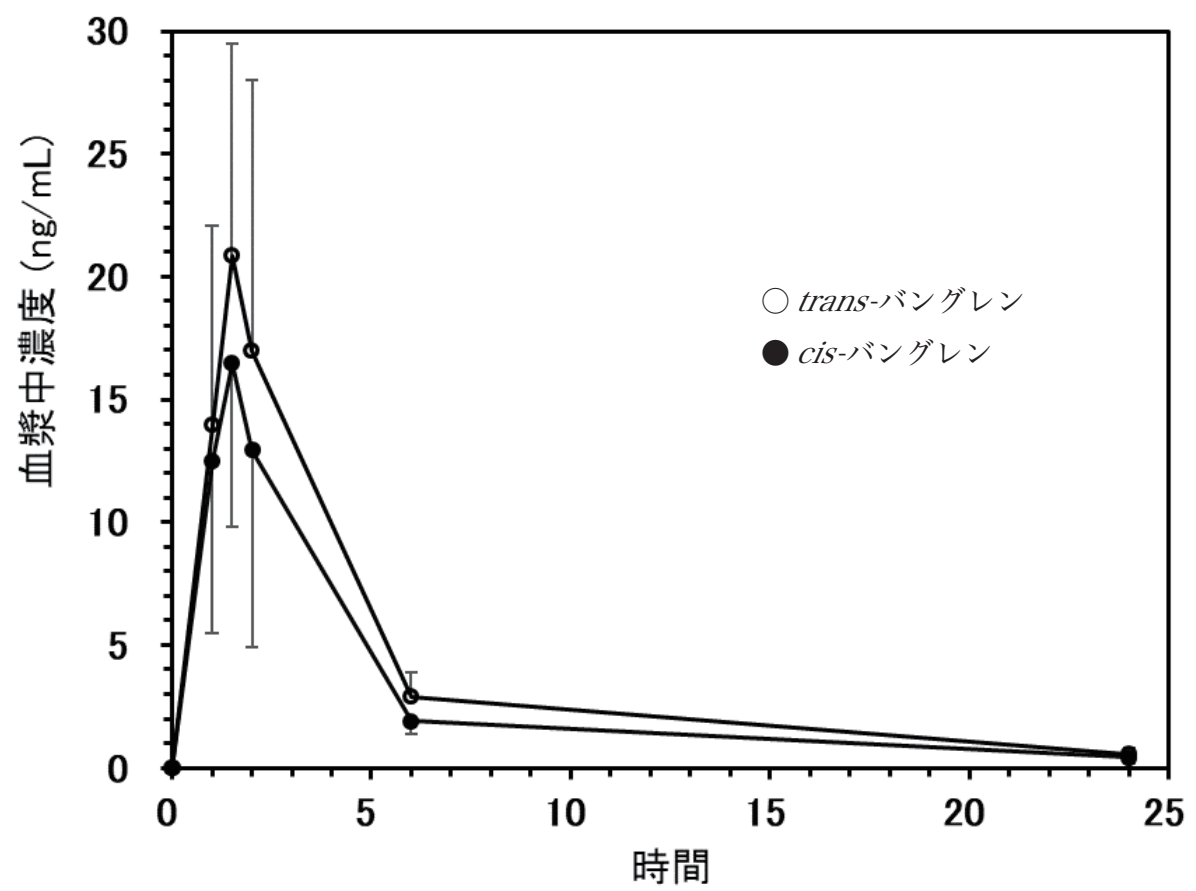

図 3 ジャワしょうが由来バングレンの血中動態（提供; 株式会社ホソダ SHC）

健常者 5 名（32-54 歳の男女）がジャワしょうがバングレ $850 \mathrm{mg}$ を経口摂取した際の trans-バングレン（○）と cis-バングレン（の）の 24 時間の血漿中濃度のグラフ

場はまだまだ先のことである。したがって, 脳機能改善作 用を有する安全性の高いサプリメントの研究開発は世界中 から渴望されているとも言えよう。

以下にジャワしょうがバングレのこれまでの研究報告を 説明する.

1）徳島文理大学の研究グループは, ジャワしょうがバ ングレに含まれるtrans-バングレンと cis-バングレンの神 経細胞活性化作用を調べた結果，前者は $10 \mu \mathrm{M}$, 後者は $30 \mu \mathrm{M}$ の濃度で PC12 細胞の分化誘導活性を示すこと(図 4), さらにラット胎児大脳皮質由来初代培養神経細胞に 対していずれも $3 \mu \mathrm{M}$ の濃度で神経突起伸展促進活性を 示すことを報告した ${ }^{1)}$.

さらに, 認知情動障害モデルマウス（嗅球摘出マウス; Olfactory bulbectomy mice) にtrans-バングレンとcisバングレンを 2 週間経口投与し, 摘出した脳の海馬の歯 状回顆粒細胞層の凍結切片を作製し, 成熟神経細胞マー カーである NeuNの抗体と新生された細胞を識別する マーカーとして用いられている BrdU 抗体を用いて, 両陽 性細胞を計測した結果，いずれも脳神経細胞の新生を促進 することが分かった（図 5)。さらに，マウスにtrans-バ ングレンまたは cis-バングレンを経口投与して経時的に血 漿中および脳内濃度を測定した結果，いずれも血中および 脳内へ移行することも示された。すなわち,バングレンは, いわゆる血液脳関門 (blood-brain barrier: BBB) を通過す ることが初めて明らかとなった ${ }^{1)}$.

以上の結果から, ジャワしょうがバングレは, 認知症の 予防もしくは改善に有用であることが示唆された。
2）ジャワしょうがバングレには，バングレンとは別にク ルクミノイド 2 種が見出され, PC12 細胞における分化 誘導活性作用が調べられた。これらのクルクミノイドは, NGF 非存在下では突起伸展作用は認められなかったもの の, NGF 存在下では, NGF 単独の 2 倍以上の突起伸展作 用を示すことが分かった ${ }^{2)}$. また，これらのクルクミノイ ドは，アルッハイマー型認知症の発症に深く関与するとさ れているアミロイド $\beta$ タンパク質の凝集を阻害する作用を 有していることも判明し，その作用はtrans-バングレンよ りも強かった。

以上のことから，ジャワしょうがバングレの中にはバン グレン以外にも, クルクミノイドなど脳機能に寄与する成 分が含まれることが明らかとなり, より一層, ジャワしょ うがバングレの脳機能改善作用に期待が高まった。

3) 高知大学の仲井らと徳島文理大学の福山らのグループ は，ジャワしょうがバングレの摂取が，学習や記憶に対 してどのように影響するかについて動物実験で解明した ${ }^{7)}$ (図 6). 学習・記憶障害を伴う老化促進マウス (SAMP8; Senescence-Accelerated Mouse P8) にジャワしょうがバ ングレ $100 \mathrm{mg} / \mathrm{kg} /$ 日 (バングレンとして $10 \mathrm{mg} / \mathrm{kg} /$ 日) を 28 日間混䭒投与した。 その後, モーリスの水迷路試験 (Morris water maze) を行った. モーリスの水迷路試験と は，空間学習能力と記憶力を測定するための行動試験であ る.

ジャワしょうがバングレを摂餉した群の老化促進マウス は，6 日間のトレーニングによって足が付くプラットホー ムまでの到達距離が短縮し, 学習能力及び記憶力改善効 


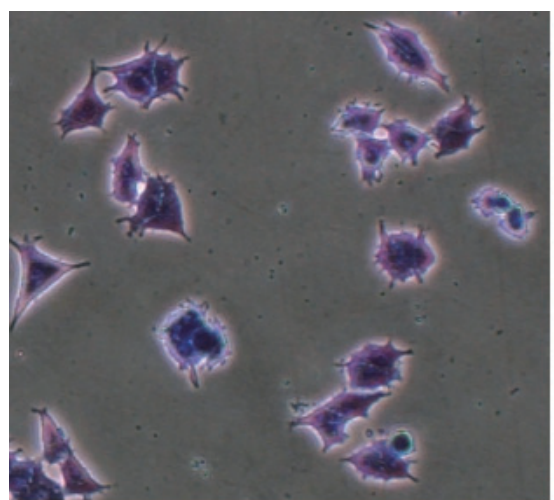

コントロール

$(0.5 \% \mathrm{EtOH})$

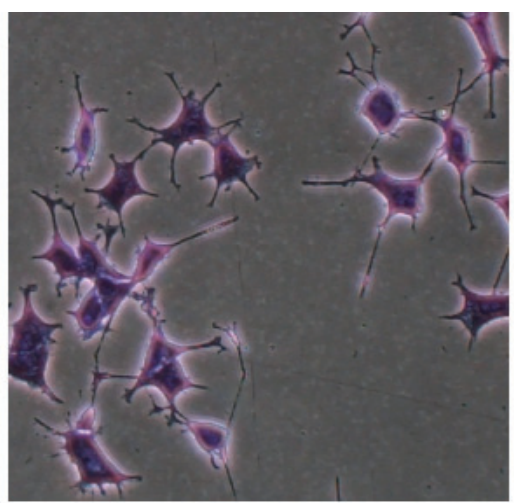

ポジティブコントロール

NGF (10 ng/mL)

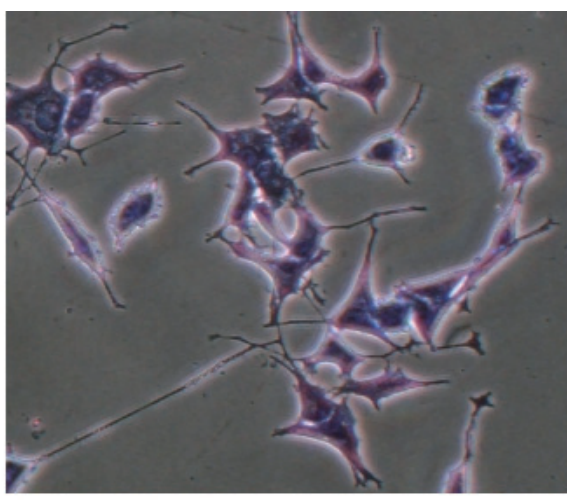

cis-バングレン

$(30 \mu \mathrm{M})$

図 4 ジャワしょうがバングレの神経細胞活性化効果（提供 ; 福山愛保先生）

ヒト血清 HS10\%とウシ胎児血清 FBS5\%を添加した DMEM（ダルベッコ改変イーグル培地）を用いて，神経分化のモデル細胞である PC12 細胞を 2 $\times 10^{3}$ 細胞 $/ \mathrm{cm}^{2}$ の密度で 24 時間培養した後に, 培養液を HS $2 \%$ とBS $1 \%$ を添加した DMEM 培地に交換し, 各試薬を添加して 4 日間培養した。 バ ングレンは，NGF (Nerve growth factor; 神経成長因子) 非存在下においても突起伸展促進作用を示した.

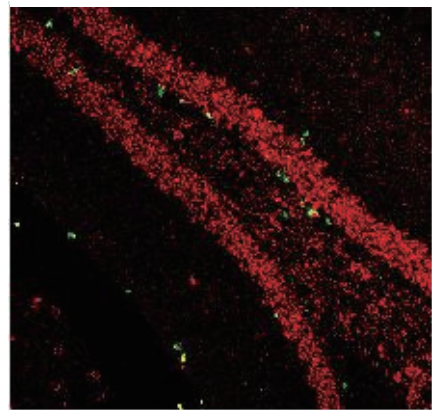

Non

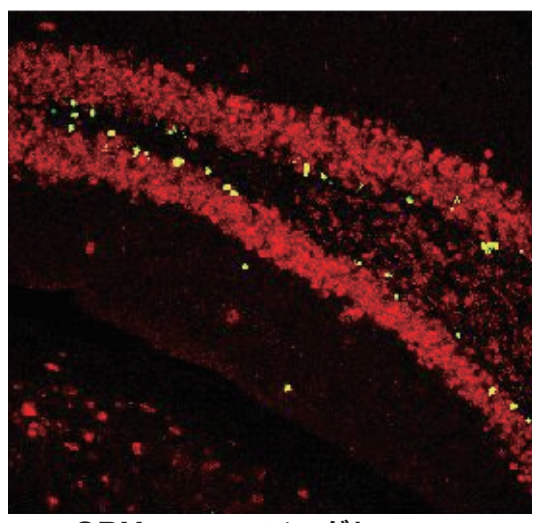

OBX+trans-バングレン

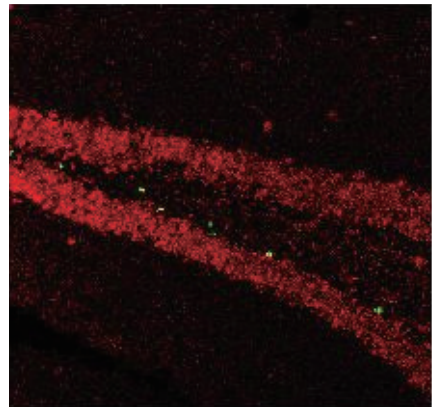

OBX

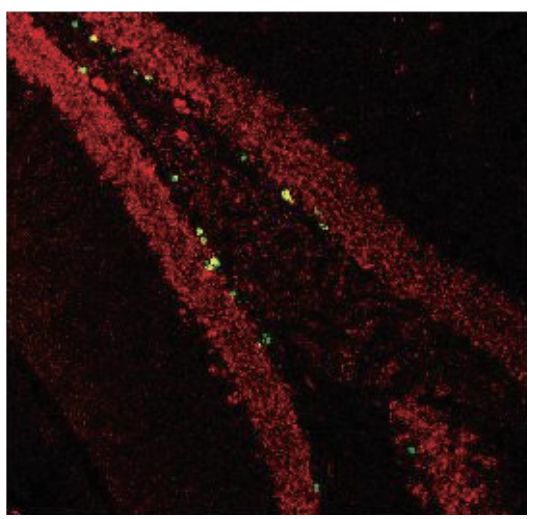

OBX+cis-バングレン

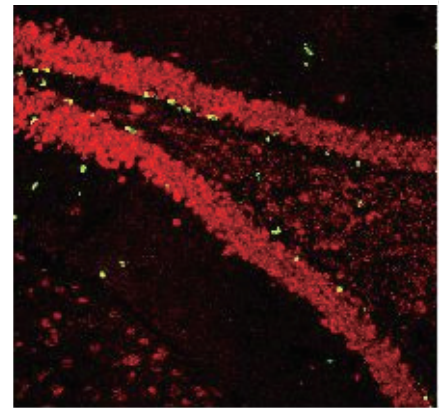

$\mathrm{OBX}+\mathrm{FLU}$

図 5 OBX マウスにおける脳神経細胞の新生促進作用（提供 ; 福山愛保先生）

嗅球摘出マウス (OBX mice) において, バングレンの経口摂取により海馬の歯状回顆粒細胞層における脳神経細胞の新生に及ぼす影響を調べた。 BrDUにより新生細胞が緑色に染色, NeuNにより神経細胞が赤色に染色され, それらが重なった部位が黄色に呈色し, 新生脳神経細胞を示している.

果が正常老化マウス (SAMR1; Senescence-Accelerated Mouse Resistant 1) と同程度まで改善した。ささらに, 当 該マウスを解剖して海馬の切片を染色して観察したとこ ろ, 脳神経細胞新生数が有意に増加していた。

4）我々は, ジャワしょうがバングレの軽度認知障害に対
する探索的臨床試験を行った ${ }^{8)}$ (図 7). 事前スクリーニ ングで, 15 名の候補者から MoCA-J の総得点が 26 点以 下 (カットオフ值) の軽度認知障害の疑いのある 7 名 (76.0 \pm 8.4 歳) を選び, 探索的オープン臨床試験を行った。被 験者は, 1 錠中にジャワしょうがバングレ $85 \mathrm{mg}$ を含有 する食品（株式会社ホソダ $\mathrm{SHC}$ 製）を朝食後と夕食後に 

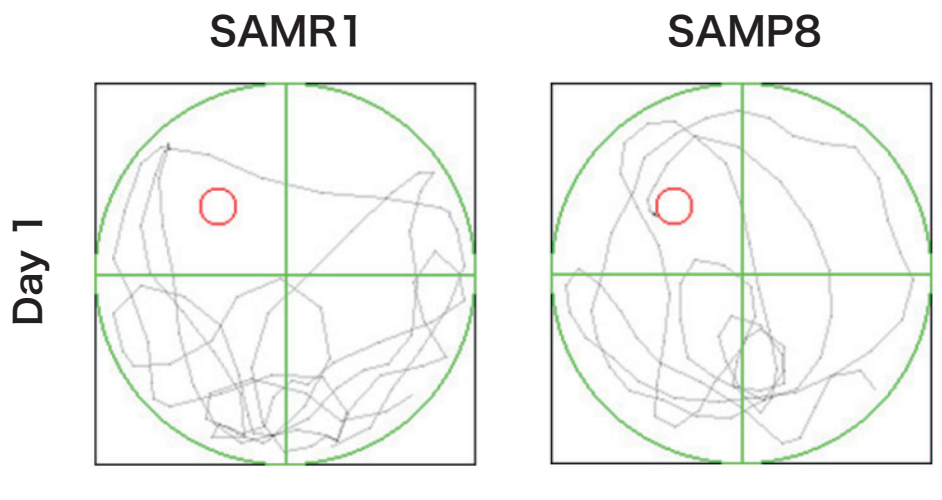

SAMP8+JGE
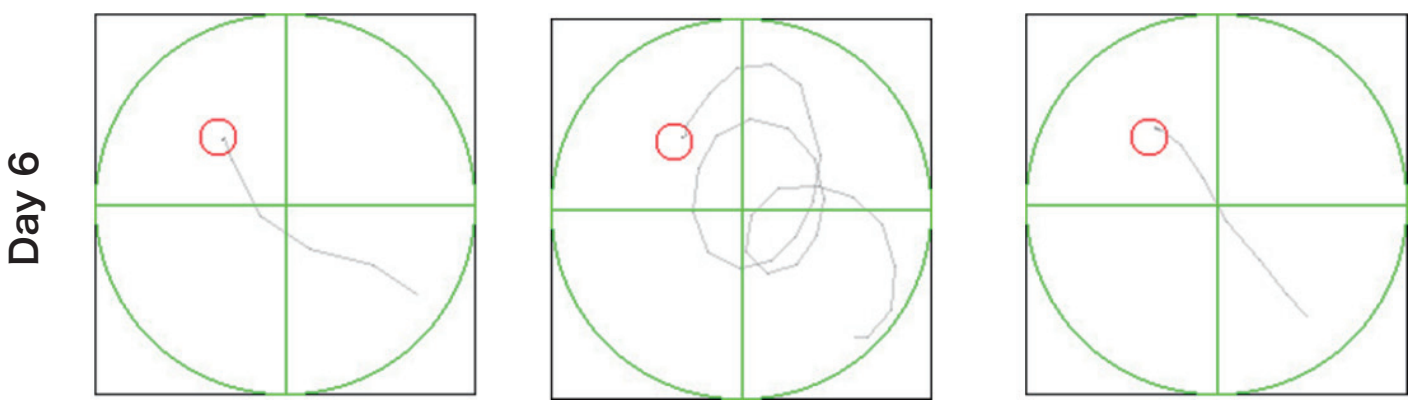

図 6 モーリス水迷路試験結果（提供; 福山愛保先生）

学習・記憶障害促進老化マウスであるSAMP8 にジャワしょうがバングレ $(\mathrm{JGE})$ を 28 日間摂取させた後，モーリスの水迷路試験を 6 日間実施した。 図の上段が 1 日目, 下段が 6 日目である.

※ SAMR1; 正常老化マウス Senescence-Accelerated Mouse Resistant 1, SAMP8; 老化促進マウス Senescence-Accelerated Mouse P8

MOCA-J 総得点

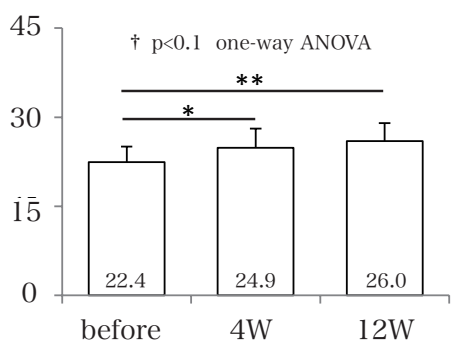

「注意」領域

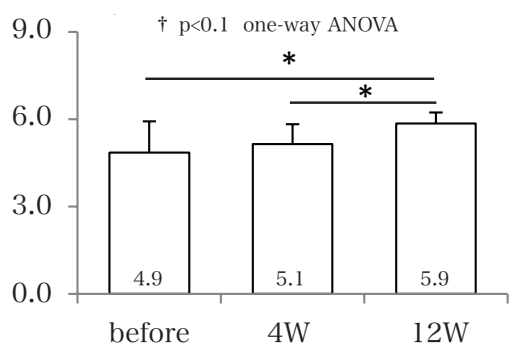

「記憶 / 遅延再生」領域

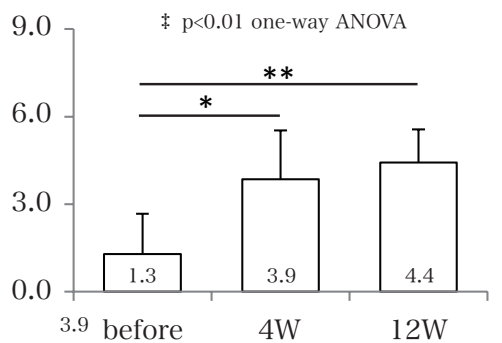

Means \pm S.D. $(\mathrm{n}=7){ }^{*} \mathrm{p}<0.05,{ }^{* *} \mathrm{p}<0.01$ vs. before (paired t test) $\quad \dagger \mathrm{p}<0.1, \quad \mathrm{p}<0.01$ one-way ANOVA

図 7 ジャワしょうがバングレの軽度認知障害に対するヒト臨床試験

（日本補完代替医療学会誌より転載許可）

それぞれ 3 錠ずつ（計 6 錠 $510 \mathrm{mg}$ ）を，12 週間継続し て摂取した。

脳機能の評価には, MoCA-J (Montreal Cognitive Assessment, 日本語版）を用いた。視空間 / 実行系, 命名, 記憶, 注意, 言語 (復唱, 語想起), 抽象概念, 記憶 / 遅 延再生，見当職など多領域の認知機能を総得点等により評 価した。

結果は，図 7 に示した。総得点は，摂取前に比べ，摂取 4 週目および 12 週目に有意に増加し $(p<0.05, p<0.01)$, one way ANOVA 解析では有意傾向が示された $(\mathrm{p}<0.1)$. さらに,「注意」領域では, 12 週目で,「記憶/遅延再生」
領域では, 4 週目と 12 週目で有意に改善した $(\mathrm{p}<0.05$, $\mathrm{p}<0.05, \mathrm{p}<0.01$ ).

以上の結果から，ジャワしょうがバングレは軽度認知障 害改善作用を有する可能性が示唆された。

\section{まとめ}

ジャワしょうがバングレは, in vitro において NGF 非 存在下でも神経細胞の新生ならびに突起伸展作用を有する ことが徐々に明らかとなってきた。 また, 動物実験で, 空 間学習能力と記憶力の改善作用も報告された。さらに, 七 
トの認知症やパーキンソン病など様々な神経疾患に対する 検討も始まった。

超高齢化を目前にひかえた医療現場においては，神経細 胞の新生や神経突起の伸展をもたらす新薬は未だ登場して いないので，ジャワしょうがバングレをはじめとする機能 性食品に寄せる期待も大きいのではないかと思われる。

\section{謝 辞}

貴重な資料をご提供いただいた徳島文理大学の福山愛 保先生に深謝いたします。また，ジャワしょうがの貴重な 基礎デー夕をいただいた株式会社ホソダ SHC の加藤榮信, 鈴木康朗，細田真也様にお礼申し上げます。

\section{参考文献}

1) Matsui N, Kido Y, Okada H, et al. Phenylbutenoid dimers isolated from Zingiber purpureum exert neurotrophic effects on cultured neurons and enhance hippocampal neurogenesis in olfactory bulbectomized mice. Neuroscience Letters. 2012; 513(1): 72-77.
2) Kubo M, Gima M, Baba K, et al. Novel neurotrophic phenylbutenoids from Indonesian ginger Bangle, Zingiber purpureum. Bioorganic \& Medicinal Chemistry Letters. 2015; 25(7): 1586-1591.

3) ジャワショウガエキス及びその製造方法（日本国特許 第 5725527 号)

4) Seidemann J. World Spice Plants. 2005: 402.

5) 美白用皮膚外用剂（日本国特許第 3140357 号）

6) Kato E, Kubo M, Okamoto Y, et al. Safety assessment of Bangle (Zingiber purpureum Rosc.) rhizome extract: Acute and chronic studies in rats and clinical studies in human. ACS Omega. 2018; 3(11): 15879-15889.

7) Nakai M, Iizuka M, Matsui N, et al. Bangle (Zingiber purpureum) improves spatial learning, reduces deficits in memory, and promotes neurogenesis in the dentate gyrus of senescence-accelerated mouse P8. Journal of Medicinal Food. 2016; 19 (5): 435-441.

8) 許鳳浩, 上馬場和夫, 浦田哲郎ら. ジャワしょうが抽出物 摂取の軽度認知障害に対する影響。日本補完代替医療学会 誌. 2018; 15(1): 65-66.

\author{
ABSTRACT \\ Java Ginger Bangle \\ Nobutaka SUZUKI ${ }^{1}$, Hoko KYO ${ }^{1}$, Kazuo UEBABA ${ }^{2}$ \\ ${ }^{1}$ Department of Complementary and Alternative Medicine Clinical Research and Development, \\ Kanazawa University Graduate School of Medical Science \\ ${ }^{2}$ Teikyo Heisei University
}

The review reveals latest studies of Bangle that has unique ingredients, safety, healthy effect and especially neurotrophin activity. Banglenes have some neurotrophin activity such as neuritogenesis without NGF in vitro, property that enhances hippocampal neurogenesis and crosses the blood-brain barrier (BBB) in vivo. On the other hand, Java ginger bangle (Extract) improves spatial learning in Senescence-Accelerated Mouse. Moreover the human clinical trial for MCI (Mild Cognitive Impairment) have been just started.

Key words: Java ginger bangle, neurotrophin-mimic active compound, banglene, dementia, MCI (Mild Cognitive Impairment), MoCA-J 